\title{
Sustainable development of "Smixi" using environmental impact assessment
}

\author{
A. G. Stergiadou \\ Faculty of Forestry and Natural Environment, \\ Institute of Mechanical Science and Topography, \\ Aristotle University of Thessaloniki, Greece
}

\begin{abstract}
The contribution of the forest of Smixi's area to the quality of life is unlimited, as it corresponds quantitively or qualitively to the needs of the inhabitants and the visitors. It is well known that the public demand for quality recreation areas is increasing rapidly because of the fast-growing seasonal population and the improvement of its citizens' income levels. The accessibility, the improvement and the quality of the forest should be one of the first priorities of the office of forestry and the municipality of Grevena. It is also necessary to enhance the level of environmental education, especially of the young, in order for the recreation areas and especially the environment to be appreciated and respected. This research develops a method to evaluate the impacts of forest road and path construction on the natural environment. The method will be used to improve the layout of forest roads and paths at an early planning stage. The method which was applied has been practical, effective and easy to use before the road or path construction. The criteria to assess the environmental impact was identified and rated by interviewing Greek forest scientists using questionnaires. A threshold will be defined for the level of compatible impacts. Road or path segments exceeding this threshold will be identified for re-design purposes to minimize negative impact on the environment. The combination will be used as a decision-support tool together with the Environmental Impact Assessment parameters, cost, existing legislation and environmental policy. Only in this way can we effectively use the forest benefits. This can contribute to an improvement in public health (both mental and emotional); a service which nowadays is scarce and not adequately appreciated.

Keywords: sustainable development, E.I.A., forest roads and paths, recreation evaluation, Smixi.
\end{abstract}




\section{Introduction}

Sustainability in modern societies seems to be an overall goal. There is a common assumption that human activities deplete natural resources. This is mainly attributed to the biodiversity loss resulted from the intensification of the human activities [11, 12]. There is however cases, such as traditional land use systems of moderate intensity, where the long interaction of man with nature has created ecosystems of special ecological value as wildlife habitats of rare or endangered species, or areas of high biodiversity that deserve conservation. Such areas known as traditional or historical cultural landscapes $[11,13,14,2]$ are usually land mosaics of various ecosystems and are often associated also with specific traditional, cultural, aesthetic and economic values $[12,16,2,9$, 22].

The sustainable development model is a challenge to the conventional form of development [4]. Conventional approaches see development as simply modernization of the global along Western lines. Modernization theory holds that the more structurally specialized and differentiated a society is the modern and progressive it is. The term "sustainable development" implies the informed and conscientious management of natural recourses, which have been exploited of utilized by humans, so that these resources may be capable of exploitation over time [3].

'Multiple-use' forest management practices adopted during the last decades (after the 1970s), have shaped the concept of sustainable forest management. The scope of this concept has been broadened by sustained yield management and nowadays it includes additional features such as forest operations quality, biodiversity and quality of life [20] (Table 1).

Table 1: $\quad$ Environmental, economic \& social values.

\begin{tabular}{|l|l|l|}
\hline $\begin{array}{l}\text { ENVIRONMENTAL } \\
\text { VALUES }\end{array}$ & ECONOMIC VALUES & SOCIAL VALUES \\
\hline Protect soil \& water quality & Sustainable productivity & $\begin{array}{l}\text { Rural development \& farm } \\
\text { forestry }\end{array}$ \\
\hline $\begin{array}{l}\text { Enhance biodiversity \& } \\
\text { landscape values }\end{array}$ & Commercial viability & Sustainable employment \\
\hline Maintain forest health \& vitality & & Amenity \& recreation \\
\hline $\begin{array}{l}\text { Protect ecological \& scientific } \\
\text { values }\end{array}$ & $\begin{array}{l}\text { Cultural \& archaeological } \\
\text { merit }\end{array}$ \\
\hline & Other community values \\
\hline
\end{tabular}

Source: Nieuwenhuis and Tiernan, [20].

The term Environmental Impact Assessment (E.I.A.) means an assessment of impact on the environment caused by anthropogenic interference [25, 26]. For a successful forest opening up project it is necessary to take into consideration the net cost of road construction as well as the cost arising from the Environment [6, $1,7,8,5,24]$. The total cost is the sum of partial cost [17].

To assure that all viewpoints are brought to the table, we should not rely on risk assessment for decision-making. Instead, we could employ a decisionmaking technique that was described in the National Environmental Policy Act 
(NEPA) of 1969, a federal law. NEPA requires that, before certain decisions can be made, all reasonable alternatives must be examined. If this approach is taken, then the public can get involved in describing and discussing all reasonable alternatives. In such a process, all viewpoints can be aired.

The key issues are as follows.

- Construction work in the field often results in environmental damage, to be more specific to get access to a forested area it is necessary to take into consideration the road net cost as well as the cost arising from the landscape and the natural environment.

- Human presence demands exploitation of the natural environment. Yet it causes interference some times with a negative effect.

\section{Study areas}

Smixi is a village at the Prefecture of Grevena - Northern Macedonia - Greece, located at the sides of Vassilitsa Mountain, the latitude (DMS) is $40^{\circ} 3^{\prime} 26 \mathrm{~N}$ and the longitude (DMS): $21^{\circ} 7^{\prime} 26 \mathrm{E}$ (Figure 1). It is the gateway for access to Vassilitsa ski centre and it is only $40 \mathrm{~km}$ west from the capital of the Prefecture and $160 \mathrm{~km}$ from Thessaloniki. The road network is old, but every year the office of forestry improves the roadnet and works on opening up of the forest, in order to cut the timber from the forest. In 1981 the population was 208 persons, in the next decade the increase of the permanents persons was $102,128 \%$ and in 2001 the population of the Smixi Village increase to 105,871\% (Figure 2). Today almost 600 people are staying at the village because of the jobs that are involved with tourism at the area.

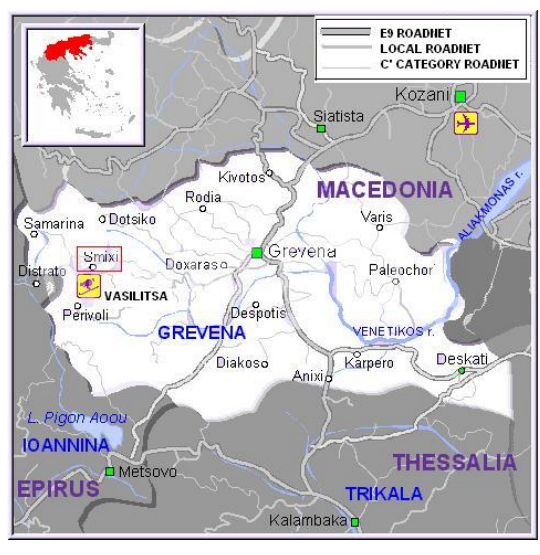

Figure 1: Topology of Village Smixi and the road net of Prefecture Grevena.

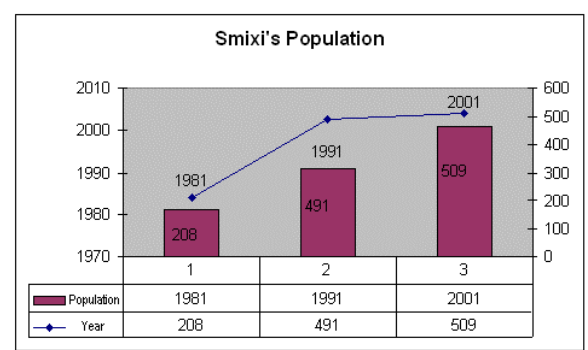

Figure 2: The Population of Smixi Village.

It is obvious that the razing of the population caused by the Ski centre at Vassilitsa Mountain as it is a tourist destination for people who want to ski, to do 
mountain bike or extreme sports at all seasons. The hotels of all categories are arisen every year with more facilities and gadgets. Tourist from all over Greece even from Europe are visiting this place because of the ski centre Vassilitsa, the marvelous flora; the wooded area with "Pinus Nigra" known as "Robola" and the unique biotope with many rare species as brown bears, wolves, lynx which are living there.

\section{Methodologies}

The methodology that was followed was practical, effective and easy to use before or after a road has been constructed [21]. For this reason practical criteria have been held in order to evaluate the intensity of the impact and absorption. The grading of these criteria depends on the following principle: "We accept a situation as ideal $(=100 \%)$ for the forest protection from construction". This ideal situation will be described by criteria.

The rating of these criteria came as a result from a survey of forest scientists by using questionnaires. The following parameters have been considered the:

1. duration of the negative effect;

2. influenced area;

3. sensitivity of the general public to the effect as well as the social impact and political desire. (The evaluation of the later parameters will be difficult and therefore the description of an E.I.A. in a profile form will be a necessary addition $[10,16,19,28])$.

E.I.A. of existing roads, in the research area will reveal different forms of absorption of negative impacts along the roads [12, 23, 27]. This information will be used to assess the impacts of the planned forest roads.

The equation that gives the compatibility with the natural environment is:

$$
\text { C (\%) = MA (\%) } \mathbf{\text { ME }}(\%) \text {, }
$$

where $\mathrm{C}(\%)$ : Compatibility, MA(\%): Mean Absorption, ME(\%): Mean Intensity.

The identification and the rating of criteria for assessing environmental impacts of road construction combined with revealing possible mitigating effects through impact absorption will allow for comprehensive evaluations of every forest road according standards set by new EU directions. The E.I.A. is of special interest when comparing different technically dual road alignments at the planning stage. Besides assessing them against the objectives of the access planning additional criteria will be available to include impacts on the forest ecosystems. The latter will affect the road alignment in horizontal and vertical perspective and result in a solution, which is technically and environmentally acceptable. The criteria of assessing environmental impacts of forest roads will be analysed by using methods of conditions and protection of forest ecosystems. Based on the framework of the E.I.A. we must find a compatible solution in order to improve the road on the level both on the serpentine and the road draining system. The combination of forest road evaluation by E.I.A. and the sustainable development management can be used as a decision-support tool [18] together with the: 

A) E.I.A. parameters;
B) cost;
C) existing legislation;
D) environmental policy.

Sustainability is related to the quality of life in a community - whether the economic, social and environmental systems that make up the community are providing a health, productive, meaningful life for all community residents, present and future. A view of community that shows the links among its three parts: the economic, the social and the environmental. Sustainable measures are committed to the development and growth of sustainable communities. Figure 3 illustrates the links of sustainability between economic, social and environmental sectors [15].

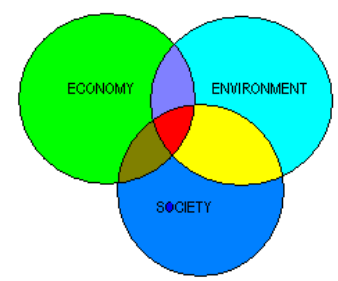

Figure 3: The links of sustainability.

\section{Results}

Based on questionnaires which have been given to the: villager of Smixi, hotel residence and skiers of the ski centre of Vassilitsa; we composed a Table 1; where we can evaluate the chosen forest road of C' category - with length of $1,5 \mathrm{~km}$ - using all the criteria of absorption and the intensity. The equation that gives the compatibility of forest road with the natural environment is:

$$
\mathrm{C}(\%)=\mathrm{MA}(\%) \mathrm{X} \text { ME (\%), }
$$

where: $\mathrm{C}(\%)$ : Compatibility, $\mathrm{MA}(\%)$ : Mean Absorption, $\mathrm{ME}(\%)$ : Mean Intensity.

The criteria of absorption are based on the terrain conditions (the kind of forest, the productivity and the slope, etc.) and on the distance from tourist places, roads, town etc. The study area is at height level over $1250 \mathrm{~m}$, so it's known as a semi- Alps biotope where there is not so forested area. That is shown at the tables below from the grade of $70 \%$. The productivity is also not so good cause of the mixed forest we found at the area and the thunders that hits the higher trees known as "Robola" (Pinus Nigra). The steep terrain and the big slopes are also an issue that keeps the forest office personal away of the forest; in order the productivity is getting lower and lower every year.

In Table 2 we can see how can we evaluate the forest road of our study area, by using criteria of absorption and intensity. 
Table 2: Evaluation of the forest road.

\begin{tabular}{|c|c|c|c|c|c|c|c|}
\hline \multicolumn{8}{|c|}{$\begin{array}{c}\text { EVALUATION OF ABSORPTION \& INTENSITY } \\
\text { OF FOREST ROAD }(1,5 \mathrm{~km})\end{array}$} \\
\hline \multicolumn{4}{|c|}{ CRITERIA OF ABSORPTION } & \multicolumn{4}{|c|}{ CRITERIA OF INTENSITY } \\
\hline \multirow[t]{2}{*}{$\begin{array}{l}\text { Terrain } \\
\text { conditions }\end{array}$} & \multirow[t]{2}{*}{$\begin{array}{l}\text { Weight } \\
\text { (1) }\end{array}$} & \multicolumn{2}{|c|}{$\begin{array}{l}\text { Forest road C' } \\
\text { category }\end{array}$} & \multirow[t]{2}{*}{$\begin{array}{l}\text { Terrain } \\
\text { allocation }\end{array}$} & \multirow[t]{2}{*}{$\begin{array}{l}\text { Weigh } \\
\text { (1) }\end{array}$} & \multicolumn{2}{|c|}{$\begin{array}{l}\text { Forest Road } C^{\prime} \\
\text { category }\end{array}$} \\
\hline & & $\begin{array}{l}\text { Grade } \\
\%(2)\end{array}$ & $(1) \times(2)$ & & & $\begin{array}{l}\text { Grade } \% \\
\text { (2) }\end{array}$ & $\begin{array}{l}(3)= \\
(1) \times(2)\end{array}$ \\
\hline Forest & 3 & 70 & 210 & Curve radius & 2,1 & 40 & 84 \\
\hline $\begin{array}{l}\text { Mixed } \\
\text { forest }\end{array}$ & 3 & 60 & 180 & Gradient & 2,01 & 60 & 120,1 \\
\hline High forest & 3 & 80 & 240 & $\begin{array}{l}\text { Gross } \\
\text { section }\end{array}$ & 2,25 & 60 & 135 \\
\hline $\begin{array}{l}\text { Selection } \\
\text { forest }\end{array}$ & 3 & 40 & 120 & Road width & 2,04 & 50 & 102 \\
\hline $\begin{array}{l}\text { Mean } \\
\text { height }\end{array}$ & 3 & 70 & 210 & $\begin{array}{l}\text { Road } \\
\text { gradient }\end{array}$ & 2,52 & 60 & 151,2 \\
\hline $\begin{array}{l}\text { Side } \\
\text { quality }\end{array}$ & 3 & 30 & 90 & Serpentine & 2,13 & 50 & 106,5 \\
\hline $\begin{array}{l}\text { Productivit } \\
\mathrm{y}\end{array}$ & 3 & 50 & 150 & \multicolumn{2}{|c|}{ Position of road } & & \\
\hline Slope & 2 & 60 & 120 & $\begin{array}{l}\text { Distance of } \\
\text { water flow }\end{array}$ & 1,83 & 100 & 183 \\
\hline Exposition & 2 & 70 & 140 & $\begin{array}{l}\text { Distance of } \\
\text { forest } \\
\text { boundary }\end{array}$ & 1,65 & 80 & 132 \\
\hline Relief & 2 & 50 & 100 & $\begin{array}{l}\text { Area with } \\
\text { construction } \\
\text { problems }\end{array}$ & 2,40 & 90 & 216 \\
\hline $\begin{array}{l}\text { Distance } \\
\text { from }\end{array}$ & & & & \multicolumn{2}{|c|}{ Picture of landscape } & & \\
\hline $\begin{array}{l}\text { Tourist } \\
\text { places }\end{array}$ & 1 & 60 & 60 & From terrain & 1,83 & 80 & 146,4 \\
\hline Highway & 1 & 30 & 30 & Vegetation & 1,8 & 80 & 144 \\
\hline Railway & - & - & - & View effect & 1,7 & 100 & 170 \\
\hline $\begin{array}{l}\text { Archaeolog } \\
\text { ical Sites }\end{array}$ & 1 & 60 & 60 & $\begin{array}{l}\text { Compatible } \\
\text { Constructions }\end{array}$ & 1,6 & - & - \\
\hline Town & 1 & 80 & 80 & $\begin{array}{l}\text { View of water } \\
\text { flow }\end{array}$ & 1,65 & 60 & 99 \\
\hline Village & 1 & 60 & 60 & \multicolumn{2}{|c|}{$\begin{array}{l}\text { Forest road construction } \\
\text { (only for existing road) }\end{array}$} & & \\
\hline Path way & 1 & - & - & $\begin{array}{l}\text { Earth works } \\
\text { machinery }\end{array}$ & 2,16 & 70 & 151,2 \\
\hline TOTAL & 29 & & 1850 & Material & 2,08 & 100 & 208 \\
\hline \multirow[t]{5}{*}{$\begin{array}{l}\text { Avarege } \\
\text { clause } \\
\text { (3) X (1) }\end{array}$} & & & \multirow[t]{5}{*}{$63,79 \%$} & $\begin{array}{l}\text { Seeding and } \\
\text { mulching of } \\
\text { side slope }\end{array}$ & 1,38 & 80 & 110,4 \\
\hline & & & & $\begin{array}{l}\text { Road drainage } \\
\text { system }\end{array}$ & 2,31 & 60 & 138,6 \\
\hline & & & & $\begin{array}{l}\text { Visual } \\
\text { absorption } \\
\text { capability }\end{array}$ & 1,77 & 70 & 123,9 \\
\hline & & & & TOTAL & 37,21 & & $25,21,1$ \\
\hline & & & & $\begin{array}{l}\text { Average } \\
\text { clause } \\
\text { (3) X (1) }\end{array}$ & & & $67,75 \%$ \\
\hline
\end{tabular}




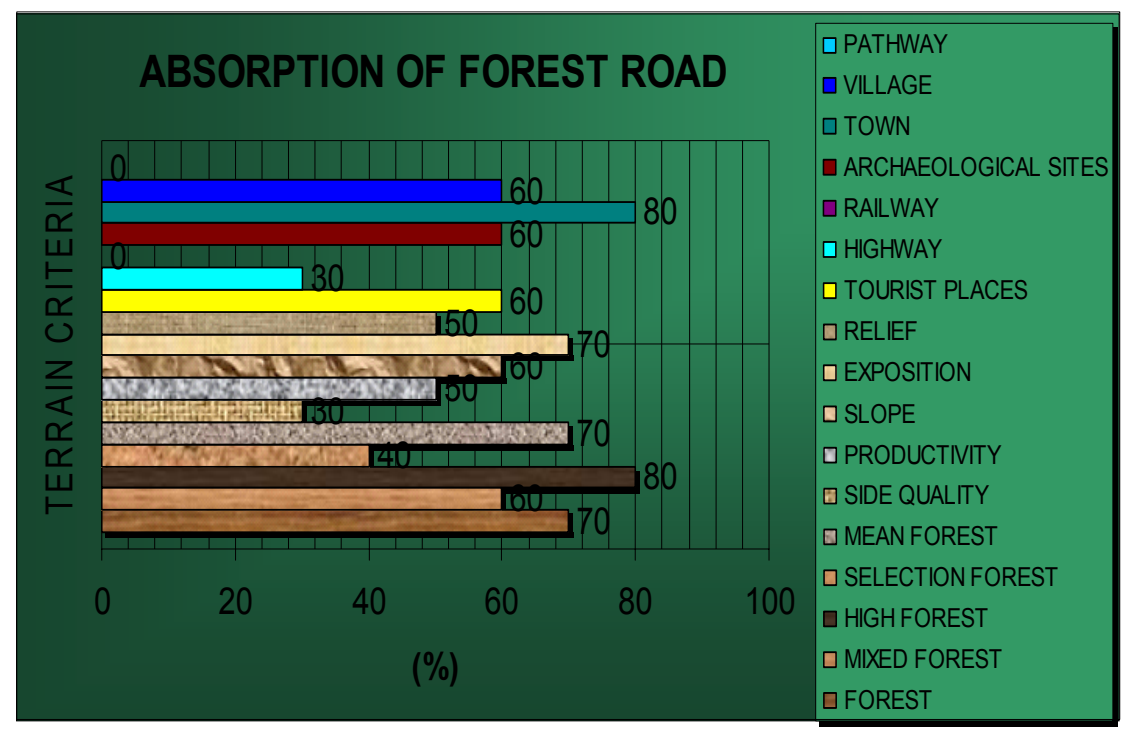

Figure 4: Absorption percentage at the forest road.

The gradation of absorption criteria (Figure 4) is based on the kind of terrain conditions and the distance between the constructing forest road and other interesting locations as the ski centre.

The values of the weights are:

- 1 for minimum weight (not important),

- 2 for medium weight (important) and

- 3 for maximum weight (very important).

It is also well known that the absorption can be measured by the:

1) type of forestall plants (pinus, acer, etc),

2) topography of the location and

3) Social interest.

\section{Conclusions and policy implications}

Based on the Tables 1 and 2 above we came to the following conclusions:

A) The Table 2 shows that the forest road of C' Category has an absorption $(63,79 \%)$. At this forest road the terrain conditions were graded as: not so forested, with medium height plants, a small productivity and max exposition.

B) The distance from Tourist places, Archaeological sites, villages and pathways has been in an average $60 \%-80 \%$, which is good but not good enough.

C) The forest road of C' Category shows compatibility nearly $70 \%(=67$, $75 \%$ ), so it is over than the $50 \%$ which is necessary in order to accept the existing road as a compatible road with the natural environment. 
In cases where the road shows no compatibility (less than 50\%) then this road is not accepted and it is suggested that the technical specifications of the staking grade line should be improved. In our case that in not necessary.

According to the research results it is suggested:

- A list of criteria (Table 1) and their weights to evaluate the intensity of the impact from road construction and the absorption ability will be very useful and practical for the assessment by the Environmental Impact Assessment. Such a profile form based on European Union directions, will be useful to every office of forestry.

- It could be very useful to have alternative road construction solutions for comparison based on the new planning technique according to the aims of opening up the forest, terrain conditions and the protection of forest ecosystem, before the forest road is constructed.

- The staking grade line of one road in a Digital Terrain Model will be easiest to use for the comparison of more than one road alternative, in order that the best solution be taken.

- $\quad$ Road segments exceeding this threshold will be identified for re-design purposes to minimize negative impacts on the environment.

- It is of maximum importance in sensitive ecological systems such as Mediterranean forest areas, to have a realistic concept by designing the opening up of forests.

- To use a real-time expert system environment designed for on-line dynamic decision support, mission critical command and control and communicate with offices of forestry, universities, etc.

- The existence of a profile form based on European Union directions for Environment Impact Assessment; can be used also as a decision-making tool, for re- design purposes of existing roads.

The existing legislation and the local environmental policy which held in Greece can give new directions to the offices of forestry in the section of construction works.

Sustainable principles are implemented through the following actions:

1. conservation and protection of high productivity forest land;

2. prevention of the quality degradation of forest land (erosion, pollution from traffic, etc.);

3. protection of the quality of surface and underground waters;

4. protection and reservation of ecological sensitive areas.

Obviously, that there are various problems concerning constructing of forest road net, forest administrative and management issues. It is essential that administrative and management practices enhance forests' role and functions. A sustainable development needs a corporation between ministries, local population and the Prefecture of Grevena in order to achieve a balanced socioeconomic development by respecting the ecosystem and nature of the study area.

\section{References}

[1] Becker, G., Walderschließung auf dem Prüfstand, AFZ, BLV Verlagsgesellschaft mbh München, 1995; 9(2): 19-20 
[2] Burggraff P, Kleefeld KD. Historische Kulturlandschaft und Kulturlandschaftselemente. Angew. Landschaftsökologie 1998; 20.

[3] Chatzieustathiou M., Spilanis I., Vayanni H. Developing a method to evaluate the contribution of different Human activities to the Sustainable development of Islands: a case study on Marine Aquaculture. Proc. of the 2006 Naxos International Conf. on Sustainable Management and Development of Mountainous and Island Areas, eds. E-media, HeraclionCreta, pp $78-87,2006$.

[4] Christopoulou O., Polyzos S., Minetos D.: Peri-urban and urban forests in Greece: Obstacle or advantage to urban development? Proc. of the 2006 Naxos International Conf. on Sustainable Management and Development of Mountainous and Island Areas, eds. E-media, Heraclion- Creta, pp 88 $96,2006$.

[5] Giannoulas V, Doukas K, Drosos V, Soutsas C. The Environment Impact Assessment (E.I.A.) by the forest opening up in the forest complex of Down Olympus. In: Bulgarian Academy of Sciences. Proceedings of the third Balkan scientific conference on Study, Conservation and Utilization of Forest Resources; 2001 October 2-6; Sofia, Bulgaria. Sofia: Forest Research Institute;2001. Volume I, p. 58-66, 2001.

[6] Doukas, K., Erschließungsmodelle und Umweltschutz, Tagungsbericht über das 28 Internationales Symposium FORMEC in Langnah, I. E. Schweiz; pp. 318-326, 1994.

[7] Doukas, K., Akca, A., Umweltverträglichkeitsprüfung bei der Walderschließung in Griechenland, Algemeinen Forst und Jagdzeitung, J. D. Sauerlaenders Verlag, Frankfurt am Main 1999; 17(3):27-28.

[8] Doukas, K., Forest Constructions and Natural Environment. Thessaloniki: Yiachoudis Publishing; 2004.

[9] European Commission. Europe's environment: the second assessment. Brussels: DG for Environment; 1998.

[10] Eskioglou, P., Environmental Studies. Environmental Impacts from the design, construction and use of road works, Scientific Seniority of Department of Forestry and Natural Environment, Thessaloniki, 1994; 27: $497-516$.

[11] Ewald KC. Traditionelle Kulturlandschaften. Der Bürger im Staat 1994; 44 (1): 37-42.

[12] Heinimann R.H., Umweltverträglichkeit forstlicher Erschließungen-das scheizerische Prufverfahren, Scientific Seniority of Department of Forestry and Natural Environment, Ehrenband von Prof. G. Stergiadis, Thessaloniki, 1992; LD(2):589-600.

[13] Glowka L, Burhenne-Guilmin F, Synge H. A guide to the Convention on Biological Diversity. Gland: IUCN; 1994.

[14] IUCN, edition. Parks for Life: Action for Protected Areas in Europe. Gland: IUCN; 1994.

[15] Korres G., Marmaras E., regional planning and sustainable development: a case study for Greek islands - Naxos, Proc. of the 2006 Naxos International Conf. on Sustainable Management and Development of 
Mountainous and Island Areas, eds. E-media, Heraclion- Creta, pp 217 229,2006.

[16] Koutsopoulos, K., Kophitsas, I., A Procedure for the Estimation of the Environmental Impacts of a Road, Technical Chronic, Athens, Greece, 1984; 4(1-2): $14-17$.

[17] Meeus JHA. Pan-European Landscapes. Landscape and Urban Planning 1995, 3: 57-79.

[18] Montague P., Making good decisions, http:/www.gdrc.org/uem/eia/ [30/06/2006].

[19] Mousiopoulos, N., Specification for studies in Environmental Impact (Analytical terms, structures and directions), Thessaloniki, Greece: Second Edition, Ziti Press; 1999.

[20] Nieuwenhuis M, Tiernan D. The Impact of the Introduction of Sustainable Forest Management Objectives of the Optimisation of PC - Based Forest - Level Harvest Schedules. Forest Policy and Economics 2005; 7: 689701 .

[21] Organization for Economic Co-operation and Development (OECD) Environment Directorial, Environmental Impact Assessment for Roads, 1994; A-B, Road Transport Research. http://www.oecd.org [30/6/2006].

[22] Phillips A. Cultural Landscapes: an IUCN Perspective. In: von Droste B, Plachter H, Rössler M, editors. Cultural landscapes of universal value: Components of a Global Strategy. Jena: G-Fischer; 1995: p.380-392.

[23] Plachter H. Functional criteria for the assessment of cultural landscapes. In: von Droste B, Plachter H, Rössler M, editors. Cultural landscapes of universal value: components of a global strategy. Jena: G-Fischer; 1995. p. 393-404.

[24] Sedlak O., Walderschließung und Naturschutz, Forstzeitung, Wien, 1993; $7(2): 8-11$.

[25] Stergiadou A., Stergiadis Ch. Giannoulas V., Doucas K., The contribution of different GPS type's in sustainable development (Case: mountain Chortiatis - Kissos)", Proceedings of $8^{\text {th }}$ International Conference on Environmental Science and Technology, Limnos 8 -10 September; 2003, pp.774 -781.

[26] Stergiadou A., Drosos V., Giannoulas V., Estimation of environmental effects from forest roads at Metsovo, Proceedings under publishing of $4^{\text {th }}$ National Conference for Metsovo, Metsovo 27 -30 September; NTUA, Athens; 2004

[27] Warner, M.L. Environmental Impact Analysis: An Examination of three Methodologies, Wisconsin, USA: Ph. D. Dissertation at Madison University; 1973.

[28] Weiss H., Waldstrassenbau und Landschaftschutz, Bündner Wald, Chur, Schweiz, 1986; 36(12): $13-15$. 